\title{
Mapping of the Varicella Zoster Virus Deoxypyrimidine Kinase Gene and Preliminary Identification of Its Transcript
}

\author{
MARK H. SAWYER, JEFFREY M. OSTROVE, ${ }^{1}$ JAMES M. FELSER, \\ AND STEPHEN E. STRAUS

\begin{abstract}
Laboratory of Clinical Investigation, Medical Virology Section, National Institute of Allergy and Infectious Diseases, National Institutes of Health, Bethesda, Maryland 20892
\end{abstract}

Received August 5, 1985; accepted October 30, 1985

\begin{abstract}
The varicella-zoster virus (VZV) deoxypyrimidine kinase (dPK) gene was mapped by transfection of cloned viral DNA fragments into thymidine kinase-deficient mouse $\mathrm{L}$ ( $\mathrm{LTK}^{-}$) cells and subsequent biochemical transformation of these cells to the $\mathrm{LTK}^{+}$phenotype. Such transforming activity was limited to the BamHI-H and EcoRI-D fragments of the VZV genome, which overlap by $2.2 \mathrm{~kb}$ between map units 0.50 and 0.52 . Biochemically transformed cells were shown to contain a high copy number of viral DNA sequences that had integrated into the cellular DNA. Extracts of these cells showed a higher level of dPK activity than did extracts of parental $\mathrm{LTK}^{-}$cells. With the use of Northern hybridization analysis of transformed and VZV-infected cell RNAs, it was possible to tentatively assign a 1.8-kb transcript to the VZV dPK. C 1986 Academic Press, Inc.
\end{abstract}

\section{INTRODUCTION}

Three human herpes viruses direct the synthesis of deoxypyrimidine kinases (dPK) during their replicative cycles. The enzymes encoded by herpes simplex virus types 1 and 2 (HSV-1, HSV-2) and varicella-zoster virus (VZV) have been characterized extensively. The initial mapping of the HSV thymidine kinase (TK) genes and much of our understanding of them were facilitated by the biochemical transformation to $\mathrm{LTK}^{+}$of mouse $\mathrm{L}$ cells deficient in thymidine kinase (LTK ${ }^{-}$) by inactivated virions or purified HSV DNA sequences (Munyon et al., 1971; Bacchetti and Graham, 1977; Wigler et al., 1977, 1978; Maitland and McDougall, 1977; Pellicer et al., 1978; McDougall et al., 1980; Reyes et $a l, 1982$ ). Through a judicious selection of sequentially smaller viral DNA fragments for such transformation experiments, it was possible to localize the HSV-1 and

\footnotetext{
${ }^{1}$ Author to whom requests for reprints should be addressed at: Medical Virology Section, Laboratory of Clinical Investigation, NIAID, NIII, Building 10, Room 11N-113, Bethesda, Md. 20892.
}

HSV-2 TK genes with some precision. DNA sequence analysis has demonstrated that each of the gencs encoding the HSV-1 and HSV-2 TKs consists of an open reading frame of 1128 nucleotides capable of encoding a protein of 376 amino acids (McKnight, 1980; Wagner et al., 1981; Swain and Galloway, 1983). Three polypeptide products of the HSV-1 gene with molecular weights (MW) of $38,000,39,000$, and 43,000 have been identified by in vitro and in vivo pulse-chase experiments (Marsden et al., 1983).

VZV is also known to induce an enzyme with dPK activity in infected cells (Dobersen et al., 1976; Ogino et al., 1977; Hackstadt and Mallavia, 1978; Cheng et al., 1979), and cell-associated VZV has been used to biochemically transform LTK $^{-}$cells (Yamanishi et al., 1981). Studies of dPK activity in VZV-infected cells suggest that this activity is associated with a $35,000 \mathrm{MW}$ polypeptide that may exist as a $70,000 \mathrm{MW}$ protein composed of nearly identical subunits (Lopetegui et al., 1983; Shiraki et al., 1985).

In this report, we describe the stable transfer of VZV dPK activity to $\mathrm{LTK}^{-}$cells by transfection of cloned viral DNA re- 
striction fragments. This process has allowed the mapping of the VZV dPK gene, the preliminary enzymatic characterization of its product, and the tentative identification of its primary transcript.

\section{MATERIALS AND METHODS}

Cell culture. The LTK ${ }^{-}$cells (a gift from M. Rao and R. Klausner) were propagated in Eagle's minimum essential medium (EMEM) (Quality Biological, Inc., Gaithersburg, Md.) supplemented with $10 \%$ fetal calf serum, penicillin $\mathrm{G}$ at $100 \mathrm{units} / \mathrm{ml}$, streptomycin at $100 \mu \mathrm{g} / \mathrm{ml}$, and bromodeoxyuridine (BUdR) (Sigma Biochemicals, St. Louis, Mo.) at $20 \mu \mathrm{g} / \mathrm{ml}$. Prior to transfection, the cells were passed at least twice in the absence of BUdR. $\mathrm{LTK}^{+}$transformants were selected and grown in EMEM supplemented with serum, antibiotics, and HAT (hypoxanthine, $15 \mu \mathrm{g} / \mathrm{ml}$; aminopterin, $1 \mu \mathrm{g} / \mathrm{ml}$; and thymidine, $5 \mu \mathrm{g} / \mathrm{ml}$ ) (Littlefield, 1963). Vero cells (African green monkey kidney cells) were grown in a mixture of EMEM and medium 199 (1:1) (Quality Biological, Inc.) also supplemented with $10 \%$ fetal calf serum and antibiotics.

Viral and cellular DNA purifications. $E c o$ RI and BamHI digests of whole VZV DNA were cloned into $\lambda \mathrm{gtWES} \cdot \lambda \mathrm{B}$ as previously described (Straus et al., 1982). The digests were further subcloned into $\mathrm{pBR}$ $322, \mathrm{pBR} 325$, and PUC8 and then grown in LE392, HB101, and JM83. Plasmid DNAs were prepared by the method of Birnboim and Doly (1979) and further purified with two isopycnic bandings in cesium chloride followed by ethanol precipitation. A DNA probe prepared for use in Southern and Northern blot analyses consisted of the 2.2kb overlapping fragment between $B a m \mathrm{HI}$ $H$ and EcoRI-D. Twenty micrograms of BamHI-H DNA in pBR 322 was digested with $B a m \mathrm{HI}$ and $E c o \mathrm{RI}$, and the bands were resolved on a $0.8 \%$ agarose gel. The 2.2-kb fragment was electro-eluted from the gel and purified through a Nacs-Prepac column [Bethesda Research Laboratories (BRL), Gaithersburg, Md.].

Cellular DNA was prepared from frozen cell pellets by overnight digestion with proteinase $\mathrm{K}(200 \mu \mathrm{g} / \mathrm{ml})$ (Sigma) in the presence of $1 \%$ sodium dodecyl sulfate, $50 \mathrm{~m} M$ ethylenediamine tetraacetic acid (EDTA), and $10 \mathrm{mM}$ Tris-HCl (pH 7.4) at $37^{\circ}$. This mixture was extracted twice with phenol and twice with chloroform; it was then precipitated overnight at $-20^{\circ}$ in 0.4 $M$ sodium acetale with $70 \%$ ethanol. The pellet was resuspended in TE buffer $(10 \mathrm{mM}$ Tris- $\mathrm{HCl}$ and $1 \mathrm{~m} M$ EDTA, at $\mathrm{pH}$ 7.4) and digested with a RNase A ( $20 \mu \mathrm{g} / \mathrm{ml}$ ) (Worthington, Freehold, N. J.) at $37^{\circ}$ for $2 \mathrm{hr}$. The DNA was reextracted with phenol and chloroform, reprecipitated in ethanol, and dialyzed overnight against TE buffer. Following an additional ethanol precipitation, the final DNA pellet was resuspended in TE buffer.

DNA transfection. Plasmid DNA fragments $(0.5-10 \mu \mathrm{g})$ were transfected into LTK $^{-}$cells in $60-\mathrm{mm}$ dishes (containing approximately $1 \times 10^{6}$ cells) using the calcium phosphate technique of Graham and van der Eb (1973) as modified by Wigler et al. (1978). Calf thymus DNA was used as carrier to achieve a final DNA concentration of $20 \mu \mathrm{g} / \mathrm{ml}$. The cell monolayers were exposed to the calcium phosphate-DNA mixture $(0.5 \mathrm{ml} / \mathrm{dish})$ for $30 \mathrm{~min}$ at room temperature before fresh medium was added. The cultures were fed $24 \mathrm{hr}$ later with HAT-containing selective media. Control dishes treated with either carrier DNA alone or no DNA were included with each experiment. As a positive control for TK transformation, we used the HSV-1 TK gene cloned into pBR 322 (HSV-106) (BRL). Colonies were isolated with the use of 5 -mm filter paper discs (Whatman, No. 1) that had previously been soaked in $0.05 \%$ trypsin with $0.1 \%$ EDTA (Quality Biological). The discs were placed over the colonies for $5 \mathrm{~min}$ and then transferred into dishes containing fresh HAT medium. The dishes were fed with fresh HAT medium every 4 to 5 days.

DNA hybridization. Cellular DNA was digested with BamHI, EcoRI, SrnaI, PstI, PvuII, SstI, HindIII, or XbaI restriction endonucleases (BRL) according to the manufacturer's instructions. The cellular DNA was electrophoresed through $1 \%$ agarose horizontal slab gels, denatured in situ, and transferred to nitrocellulose paper 
(Southern, 1975). Cloned VZV DNA fragments were labeled in vitro with $[\alpha-$ $\left.{ }^{32} \mathrm{P}\right]$ deoxycytidine triphosphate (dCTP) (sp act, $>3000 \mathrm{Ci} / \mathrm{mmol}$ ) (Amersham, Arlington Heights, Ill.) to sp act of $0.5-3.0 \times 10^{8}$ $\mathrm{cpm} / \mu \mathrm{g}$ using Nick Translation Kits (BRL). Autoradiography was accomplished at $-70^{\circ}$ with Kodak XAR-5 film in casettes fitted with Dupont Lightning-Plus intensifying screens for 2 to $16 \mathrm{hr}$. Relative DNA concentrations were estimated by densitometry. DNA fragment sizes were determined by comparison to bacteriophage lambda DNA digested with HindIII (BRL).

Northern blot analysis. Total cellular RNA was isolated from VZV-infected Flow 5000 cells (Flow Laboratories, McLean, Va.), LTK ${ }^{-}$cells, or VZV-dPK transformants. Briefly, each cell line was grown to confluence in two $150-\mathrm{cm}^{2}$ tissue culture flasks, washed three times in ice cold phosphate-buffered saline (PBS) ( $\mathrm{pH} 7.4)$, and lysed in situ with $4 M$ guanidinium thiocyanate. The lysate was layered onto a 5.7 $M$ cesium chloride cushion and centrifuged in an SW41 rotor at 33,000 rpm for $25 \mathrm{hr}$ (Chirgwin et al., 1979; Glisen et al., 1974). The supernatant was decanted, and the RNA pellet was further purified as previously described (Ostrove et al., 1985). Aliquots of cellular RNA were heated in $50 \%$ formamide, $6 \%$ formaldehyde, and $1 \mathrm{X}$ electrophoresis buffer $(20 \mathrm{mM}$ sodium [3-]N-morpholino-propane-sulfonic acid [MOPS], $5 \mathrm{mM}$ sodium acetate, and $1 \mathrm{mM}$ EDTA at pH 7.0) for $10 \mathrm{~min}$. RNA samples (4-10 $\mu \mathrm{g}$ /lane) were electrophoresed at 35 $\mathrm{mA}$ for $16 \mathrm{hr}$ through $6 \%$ formaldehyde/ $1.5 \%$ agarose horizontal slab gels (Rave et $a l ., 1979)$. The transfer of RNA to nitrocellulose and the hybridizations were carried out as previously described (Ostrove et al., 1985). RNA sizes were determined by comparison to single-stranded DNA markers.

$d P K$ assay. The various cell lines to be used for both the TK and the deoxycytidine kinase activity studies were grown to confluence in $60-\mathrm{mm}$ dishes, washed three times in PBS ( $\mathrm{pH} 7.4$ ), and scraped from the dishes. The cells were pelleted at 1500 rpm for $10 \mathrm{~min}$ in microcentrifuge tubes, and the supernatant was completely re- moved. The cell pellets were stored at $-70^{\circ}$. Pellets of each cell type to be tested were thawed on ice, and $100 \mu \mathrm{l}$ of lysis buffer was added $(10 \mathrm{mM}$ Tris- $\mathrm{HCl}$ at $\mathrm{pH} 8.0,160$ $\mathrm{m} M \mathrm{KCl}, 250 \mathrm{~m} M$ sucrose, $1.5 \mathrm{~m} M \mathrm{MgCl}_{2}$, $0.5 \% \mathrm{NP}-40$, and $3 \mathrm{mM} 2$-mercaptoethanol). The samples were vortexed twice ( $2 \mathrm{sec}$ each) and incubated on ice for $10 \mathrm{~min}$. The samples were then vortexed vigorously for 5 sec and spun for $10 \mathrm{~min}$ in a microcentrifuge $(13,800 \mathrm{~g})$. The supernatants were tested for enzyme activity (modification of Kit et al., 1973; Kit and Leung, 1974). For the $\mathrm{dPK}$ assays, $100-\mu 1$ reaction mixtures were prepared containing varying amounts of cell extract $(5-20 \mu \mathrm{l}), 50 \mathrm{~m} M$ Tris- $\mathrm{HCl}$ (pH 8.0), $5 \mathrm{mM} \mathrm{MgCl} 2,5 \mathrm{mM}$ adenosine triphosphate, $10 \mathrm{~m} M \mathrm{NaF}, 50 \mu M$ cold thymidine or deoxycytidine, and $2 \mu \mathrm{Ci}$ of $\left[{ }^{3} \mathrm{H}\right]$ thymidine or $\left[{ }^{3} \mathrm{II}\right]$ deoxycytidine (New England Nuclear, Waltham, Mass.) (modification of Yamanishi et al., 1981). Fiftymicroliter samples of the reaction mixtures were spotted onto DE81 filters (Whatman, $2.4 \mathrm{~cm}$ ), given two 60-min washes in distilled water, dipped five times in $95 \%$ ethanol, and dried. The filters were placed in Aquafluor (New England Nuclear, Boston, Mass.) and counted in a liquid scintillation counter. Enzyme activities were corrected for the amount of protein in the extracts. Protein concentrations were determined by the method of Bradford (1976).

\section{RESULTS}

Sixteen recombinant VZV DNA BamHI and $E c o$ RI fragments representing $75 \%$ of the viral genome (map units $0.18-0.66$ and $0.73-1.00$, except for about $500 \mathrm{bp}$ of the unique short segment $\left(U_{S}\right)$ were transfected into $\mathrm{LTK}^{-}$cells. The induction of stable biochemical transformants expressing TK activity was determined by formation of $\mathrm{LTK}^{+}$clones under HAT selection. This activity was occasionally observed with large amounts of calf thymus DNA and was seen with the HSV TK-containing recombinant (HSV-106) and with two fragments of VZV DNA: $B a m \mathrm{HI}-\mathrm{H}$ (map units 0.47-0.52) and EcoRI-D (map units $0.50-0.62$ ). These fragments are 
known to overlap and share a 2.2 -kb region of the genome (map units 0.50-0.52) (Straus et al., 1982) (Fig. 1).

VZV-transformed $\mathrm{LTK}^{+}$colonies developed 18 to 25 days after transfection and arose from a background of surviving cells. The majority of such surviving cells failed to proliferate into clones, perhaps demonstrating only transient expression of TK activity. No such background was seen in dishes transfected with carrier DNA alone. The VZV DNA-transformed cells resembled the parental LTK $^{-}$cells in terms of both morphology and growth rate. HSV-transformed colonies appeared more quickly (at approximately 14 days after transfection) and exhibited more rapid growth than VZV transformants. The transforming frequency of both $\mathrm{BamHI}-\mathrm{H}$ and EcoRI-D was $0.2-0.4$ colonies $/ \mathrm{dish} / \mu \mathrm{g}$ of DNA transfected, which was approximately 100 -fold lower than that seen with HSV TK genes under similar conditions.
No $\mathrm{LTK}^{+}$revertants were seen in $\mathrm{LTK}^{-}$ cells not transfected with foreign DNA, consistent with the known reversion frequency of less than $10^{-9}$ for these cells (Wigler et al., 1978).

Three stable clones resulting from the transfection of BamHI-H (BH1 and $\mathrm{BH} 2$ ) and $E c o$ RI-D (ED1) were established and have been maintained in HAT-containing media for more than 25 passages. Between passages 6 and 8 , the DNAs from these biochemically transformed cell lines were purified, and the presence within them of viral or plasmid sequences was determined by Southern hybridizations with purified VZV BamHI-H, HSV-106, or the $2.2-\mathrm{kb}$ $B a m \mathrm{HI}-\mathrm{H} / E c o$ RI-D overlap fragment as probes. All three VZV transformants, $\mathrm{BH} 1$, $\mathrm{BH} 2$, and $\mathrm{ED} 1$, were shown to contain viral and plasmid DNA sequences in high copy number (100-1000 copies per cell) (Figs. 2 and 3). Southern hybridization analysis of DNA from the VZV transformants ED1

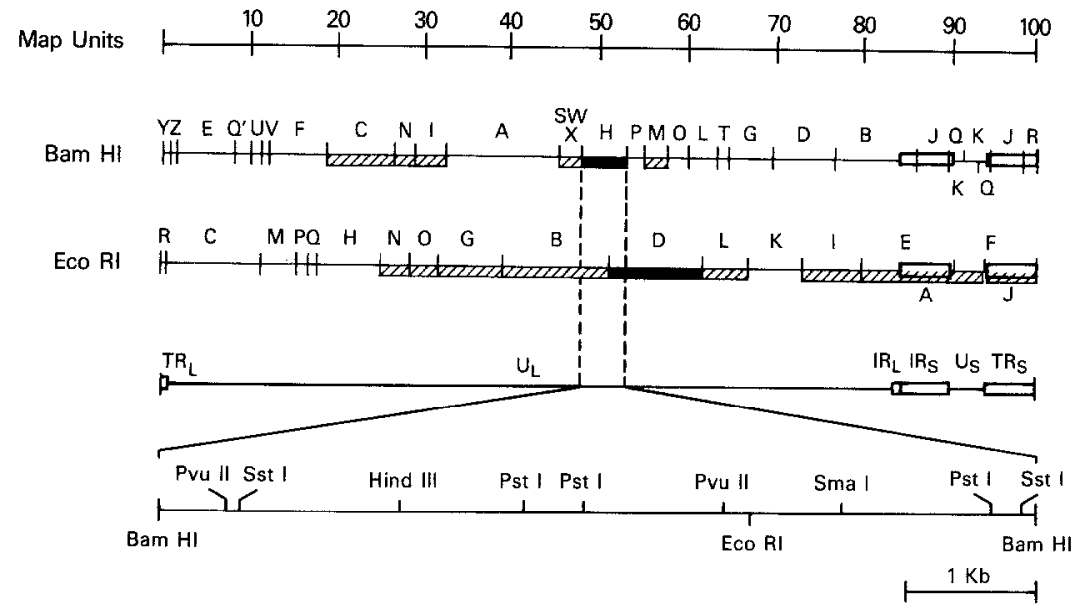

Fig. 1. Restriction endonuclease maps of the VZV genome, including the 6.7-kb BamHI-H fragment. The genome can be conveniently divided into a unique long $\left(\mathrm{U}_{\mathrm{L}}\right)$ segment bounded by small terminal and internal repeats $\left(\mathrm{TR}_{\mathrm{L}}, \mathrm{IR}_{\mathrm{L}}\right)$, and a unique short $\left(\mathrm{U}_{\mathrm{S}}\right)$ segment, bounded by large internal and terminal repeats $\left(\mathrm{IR}_{\mathrm{S}}, \mathrm{TR}_{\mathrm{S}}\right)$. The hatched areas indicate those fragments used for the transfection studies; the solid areas indicate the fragments that led to stable HAT-resistant biochemical transformants. In the transfection experiments, $5 \mu \mathrm{g}$ per dish of Bam $\mathrm{HI}-\mathrm{H}$ in pBR 322 yielded a total of 10 colonies in five dishes ( $0-3$ per dish), for a transforming frequency of 0.4 colonies $/ \mu \mathrm{g}$ of DNA per dish. EcoRI-D (7.5 $\mu \mathrm{g}$ per dish) in pBR 322 yielded six colonies in five dishes (0-5 per dish), for a transforming frequency of 0.2 colonies $/ \mu \mathrm{g}$ of DNA per dish. All other cloned fragments were tested in duplicate plates with 1.3-10 $\mu \mathrm{g}$ of DNA per dish, and no colonies were observed. Control cultures transfected with $0.5-1.0 \mu \mathrm{g}$ per dish of HSV-106 DNA routinely yielded 25-50 colonies, for a transforming frequency of $50-100$ colonies/ $\mu \mathrm{g}$ of DN $\Lambda$ per dish. The 1-kb scale marker refers to the detailed $B a m \mathrm{HI}-\mathrm{H}$ map at the bottom of the figure. 

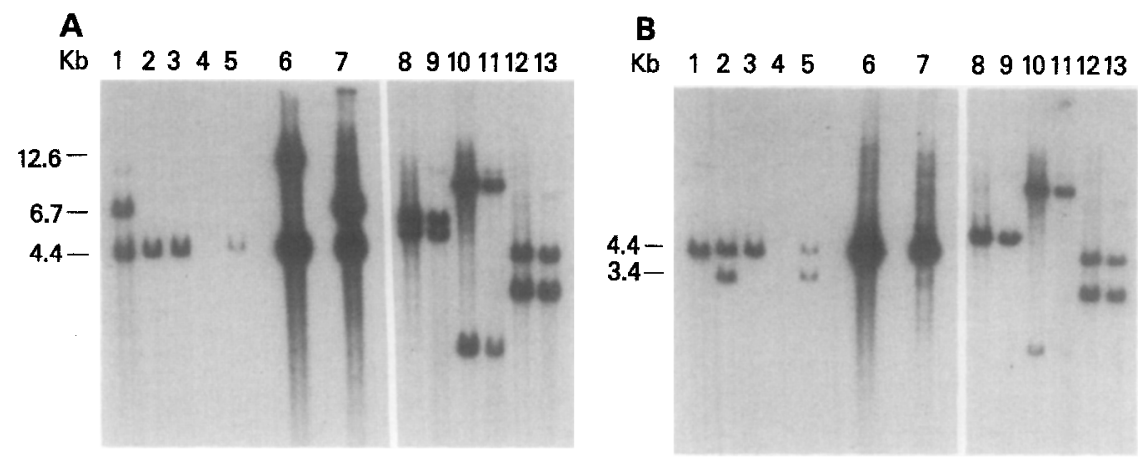

\begin{abstract}
FIG. 2. Southern blot analysis of transformed cellular DNA. Two identical blots were probed with in vitro-labeled BamHI-H in pBR 322 (A) and HSV-106 (B). In each panel, lanes 1-4 represent BamHI-cleaved DNAs and comprise reconstruction experiments with $10 \mu \mathrm{g}$ of $\mathrm{LTK}^{-}$cell DNA to which is added: in lane 1, $300 \mathrm{pg}$ of purified $\mathrm{BamHI}-\mathrm{H}$ in pBR 322; in lane 2, $50 \mathrm{pg}$ of HSV TK recombinant (HSV-106); in lane $3,75 \mathrm{pg}$ of pBR $322 \mathrm{DNA}$; and in lane 4, no addition. Lanes 5-7 contain transformed cell DNAs. These include $15 \mu \mathrm{g}$ of HSV-transformed DNA cleaved with BamHI (lane 5), $10 \mu \mathrm{g}$ of ED1 cleaved with EcoRI (lane 6), and $10 \mu \mathrm{g}$ of BH2 eleaved with BamHI (lane 7). Lanes 8-13 show paired samples of BH2 cellular DNA (450 ng/lane) and purified BamHI-H in pBR $322(300 \mathrm{pg} / \mathrm{lane})$ to which was added sufficient LTK $^{-}$cellular carrier DNA to make the total DNA $10 \mu$ g per lane. DNA was cut with SstI (lanes 8, 9), HindIII (lanes 10, 11), and PvuII (lanes 12, 13). (A) Shows hybridization with $\alpha^{32} \mathrm{P}$ in vitro-labeled BamHI-H in pBR 322. (B) Shows the hybridization with in vitro-labeled HSV-106. Autoradiography was for $15 \mathrm{hr}$ at $-70^{\circ}$.
\end{abstract}

and BH2 following cleavage with BamHI, EcoRI, SstI, HindIII, SmaI, PstI, or PvuII revealed fragments of the sizes predicted from the restriction map (see Fig. 1). This suggests that most of the transfected DNAs were incorporated intact into the cells. Digestion of BH2 DNA with XbaI, an enzyme that does not cleave the VZV BamHI-H fragment or within $\mathrm{pBR} 322$, and subsequent hybridization with a homologous VZV DNA probe revealed a single band of very high molecular weight $(>23$ kb) (Fig. 3, lane 3). Further analysis of transformed cell DNAs with enzymes that cleave within the VZV inserts or pBR 322 revealed multiple bands of higher and lower molecular weights than those of the transfected DNA fragments. The combined data indicate that much of the transfected DNA is present as tandem repeats with integration into the cellular DNA in multiple sites.

The HSV DNA transformants contained a low copy number per cell of the HSV TK gene and its associated plasmid DNA. With the conditions employed, no cross-hybridization was seen between the HSV TK sequences and the VZV sequences. Transfor- mants that arose from transfections with calf thymus DNA alone contained no sequences homologous to VZV, HSV, or pBR 322 DNAs (data not shown).

Extracts from the transformed cell lines BH1, BH2, and ED1 as well as from a cell line transformed with the HSV-1 TK gene (HSV), LTK ${ }^{-}$cells, and Vero cells were assayed for kinase activity. $\mathrm{BH} 1, \mathrm{BH} 2$, and ED1 cells demonstrated a 70- to 115-fold greater TK activity than the parental LTK $^{-}$cells (Table 1). The abilities of these cellular extracts to phosphorylate deoxycytidine were compared to their abilities to phosphorylate thymidine. It was observed that all cell lines transformed with VZV DNA showed greater deoxycytidine kinase activity than TK activity in accord with prior reports of the substrate preferences of purified VZV dPK (Dobersen et al., 1976; Ogino et al., 1977; Fyfe et al., 1982) (Fig. 4). The opposite pattern was seen with extracts from cells transformed with HSV TK and Vero cells, also in accord with prior observations with HSV TK (Fyfe et al., 1978).

Northern hybridization analysis of the cellular RNA extracted from $\mathrm{BH} 1, \mathrm{BH} 2$, 
TABLE 1

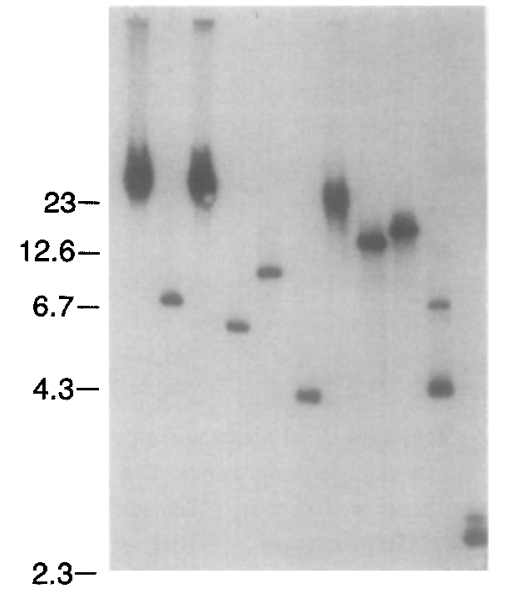

FIG. 3. Southern blot analysis of transformed cellular DNA probed with the 2.2-kb BamHI-H/EcoRID overlapping fragment. BH2- and ED1-transformed cellular DNA was cleaved with several different restriction endonucleases and probed with the gel purified, in vitro-labeled, 2.2-kb overlap fragment. Lanes 1-6 show BH2 cellular DNA. Lanes 1 and 3 each show $2 \mu \mathrm{g}$ of BH2 DNA that is undigested (lane 1) or digested with $X b a I$ (lane 3). Lanes 2, 4, 5, and 6 each show $300 \mathrm{ng}$ of BH2 DNA that is digested with BamHI (lane 2), SstI (lane 4), HindIII (lane 5), and PvuII (lane 6). Lanes 7-11 each show $150 \mathrm{ng}$ of ED1 cellular DNA that is undigested (lane 7) or digested with EcoRI (lane 8), HindIII (lane 9), SmaI (lane 10), and PstI (lane 11). Autoradiography was for $4 \mathrm{hr}$ at $-70^{\circ}$.

ED1, and LTK $^{-}$cells demonstrated the transcription of VZV-specific mRNAs in the $\mathrm{BH} 1, \mathrm{BH} 2$, and ED1 transformed cell lines. To identify the messages most likely to be associated with the transfected dPK activity, total cellular RNA from these cell lines were hybridized to the in vitro $\alpha{ }^{32} \mathrm{P}-$ labeled, gel purified 2.2-kb DNA fragment representing the region of overlap between the BamHI-H and EcoRI-D fragments. The VZV-specific messages from these transformed lines were then compared to those detected by the hybridization of VZV-infected Flow 5000 cell RNA using the same 2.2-kb overlap-fragment probe (Fig. 5). Two abundant messages of 1.8 and $2.5 \mathrm{~kb}$ were detected in VZV-infected cells. The BH1and $\mathrm{BH} 2$-transformed cell lines contained an abundant message comigrating with the
Thymidine Kinase ACTIVITIES OF ExTRACTS From VARIOUS CELL LINES

\begin{tabular}{cc}
\hline Cells & $\begin{array}{c}\text { Counts per minute } \\
\text { per microgram of protein }\end{array}$ \\
\hline LTK $^{-}$ & 15 \\
BH1 & 1041 \\
BII2 & 1751 \\
ED1 & 1043 \\
HSV & 1411 \\
Vero & 1653 \\
\hline
\end{tabular}

1.8-kb message of infected cells. The ED1 line contained only one abundant message of about $2.2 \mathrm{~kb}$ in length. Other low-abundance transcripts were seen in common in the VZV dPK-transformed cells but did not comigrate with the transcripts seen in VZV-infected cells.

\section{DISCUSSION}

With the use of the well-established technique of transfection of viral DNA

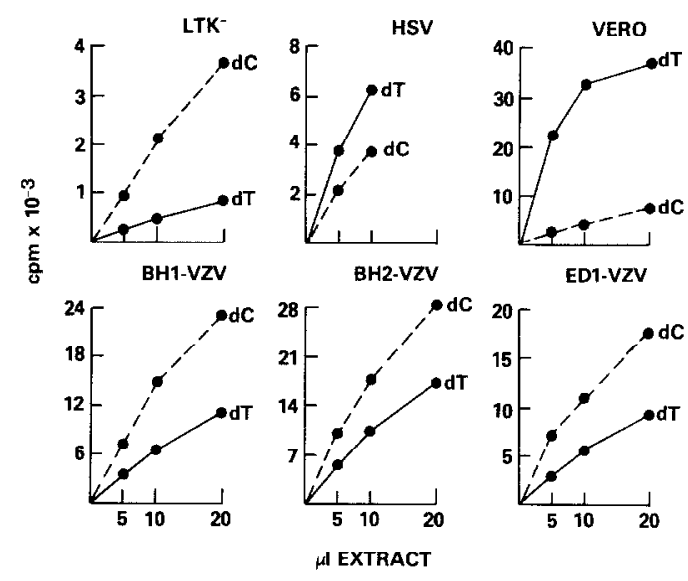

FIG. 4. Deoxypyrimidine kinase activities of cell lines. Deoxypyrimidine phosphorylation was determined for each cell line with three different amounts of cell extract: 5,10 , and $20 \mu \mathrm{l}$. Reaction mixtures were run in parallel. $\mathrm{BH} 1-\mathrm{VZV}, \mathrm{BH} 2-\mathrm{VZV}$, and ED1-VZV indicate extracts from the VZV-transformed cell lines. $\mathrm{LTK}^{-}$is the parental cell line. HSV is an extract from an HSV TK gene-transformed cell line. 


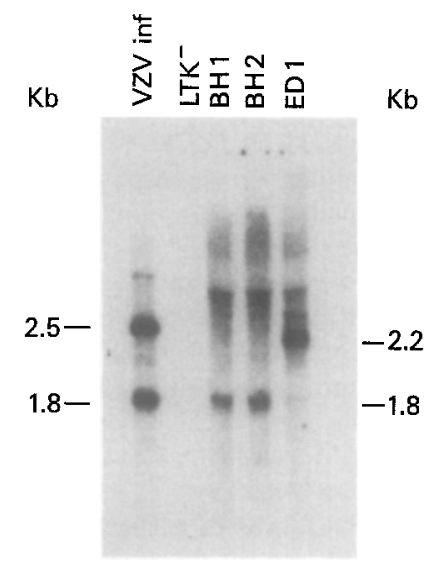

FIG. 5. Northern blot analysis of total cellular RNAs. Lane 1: $4 \mu \mathrm{g}$ of RNA from VZV-infected Flow 5000 cells. Lane 2: $10 \mu \mathrm{g}$ of RNA from $\mathrm{LTK}^{-}$cells. Lanes 3-5 contain $10 \mu \mathrm{g}$ of RNA from transformed cell lines: BH1 (lane 3), BH2 (lane 4), and ED1 (lane 5). The in vitro-labeled $2.2-\mathrm{kb}$ overlap fragment shared by $B a m \mathrm{HI}-\mathrm{H}$ and EcoRI-D was used as the probe. Autoradiography was for $5 \mathrm{hr}$ at $-70^{\circ}$.

fragments into mouse $\mathrm{LTK}^{-}$cells followed by selection in HAT medium, we were able to screen a large portion of the VZV genome for sequences capable of inducing biochemical transformation to the $\mathrm{LTK}^{+}$ phenotype. We identified two separate fragments-BamHI-H and EcoRI-D-that exhibit transforming activity. These fragments share a $2.2-\mathrm{kb}$ region of DNA, one that is large enough to encode a protein with a MW of greater than 35,000 , the presumed size of the VZV dPK (Shiraki et al., 1985), and is larger than the minimal corresponding fragment of HSV DNA needed to transfer TK activity in similar systems (Reyes et al., 1982). Although $\mathrm{LTK}^{+}$transformants were noted following transfections with calf thymus DNA alone, these cells exhibited very low TK activity and contained no viral RNA or DNA sequences.

The region of VZV DNA associated with TK transformation lies within the long unique $\left(\mathrm{U}_{\mathrm{L}}\right)$ segment of the genome, as does the HSV TK gene in its genome. Its position, at map units $0.50-0.52$, is 0.31 map units in from the $U_{L}$-internal repeat $\left(I_{L}\right)$ junction, and is similar to the distance of the HSV TK gene from the HSV terminal repeat $\left(T R_{L}\right)$ sequence. This finding is consistent with A. Davison's impression from cross-hybridization studies that the organization of the VZV genome is similar to that of HSV except for an inversion of part of the $\mathrm{U}_{\mathrm{L}}$ sequence (personal communication).

The dPK activities of the VZV-transformed cell lines were markedly greater than that of the parental LTK ${ }^{-}$cell line. Limited biochemical characterization of this activity showed that deoxycytidine was phosphorylated more rapidly than thymidine. Such findings are consistent with the reported behavior of the enzyme recovered from VZV-infected cells; however, they are the opposite of those reported for the HSV TK and those we observed in extracts prepared from HSV TKtransformed cells (Dobersen et al., 1976; Ogino et al., 1977; Fyfe et al., 1978, 1982). The VZV-transformed cell lines contained extremely high copy numbers of the transfected DNA, yet produced dPK in amounts similar to that in the HSV-transformed cell line, where copy number is usually low (Pellicer et al., 1978; Wigler et al., 1978). Some possible explanations for these findings are that the VZV dPK promoter is a weak one or that additional VZV gene products are necessary for efficient VZV dPK gene expression.

We were further able to show that three independently derived VZV DNA-transformed cell lines expressed mRNAs homologous to the segment of VZV DNA associated with the dPK-transforming activity. Only the 1.8-kb message detected in the $\mathrm{BH} 1$ and $\mathrm{BH} 2$ transformants comigrated with an abundant message expressed from this region of the genome in infected cells. The ED1 line, however, contained an abundant message of $2.2 \mathrm{~kb}$ in length. The 2.2kb transcript may originate from a fusion of the VZV dPK sequence with additional nonviral sequences and be initiated by a cellular or plasmid promoter. The $2.2-\mathrm{kb}$ transcript contains pBR 322 sequences as determined by Northern blot analysis (data not shown). If the promoter for the VZV dPK gene were to lie to the left of the EcoRI site within the BamHI-H fragment and the 
body of the message (open reading frame) were to lie to the right of the EcoRI site, then expression of the dPK by the EcoRI$\mathrm{D}$ fragment would require initiation by a nonviral promoter.

Consistent with these hypotheses are recent analyses of the VZV DNA sequence in this region of the genome. A gene with limited sequence homology to the HSV TK gene has been found in which the promoter is upstream and to the left of the adjacent EcoRI site (A. Davison, personal communication). Thus, we believe the VZV dPK gene lies between map units 0.50 and 0.52 in the $\mathrm{U}_{\mathrm{L}}$ of the VZV genome and encodes a primary $1.8-\mathrm{kb}$ transcript.

\section{ACKNOWLEDGMENTS}

The authors thank Dr. J. Hay, Dr. K. Croen, Dr. M. Rao, and Dr. J. Sherley for thoughtful advice; W. Reinhold and $\mathrm{H}$. Smith for excellent technical assistance; and $\mathrm{C}$. Crout and $\mathrm{K}$. Leighty for preparation of the manuscript.

\section{REFERENCES}

BacchetTi, S., and Graham, F. L. (1977). Transfer of the gene for thymidine kinase to thymidine kinasedeficient human cells by purified herpes simplex. viral DNA. Proc. Natl. Acad Sci. USA 74, 1590-1594.

Biknboim, H. C., and DoLY, J. (1979). A rapid alkaline extraction procedure for screening recombinant plasmid DNA. Nucleic Acid Res. 7, 1513-1523.

BRADFORD, M. M. (1976). A rapid and sensitive method for the quantitation of microgram quantities of protein utilizing the principle of protein-dye binding. Anal. Biochem. 72, 248-254.

Cheng, Y. C., Tsou, T. Y., Hackstadt, T., and MaLLAVIA, L. P. (1979). Induction of thymidine kinase and DNase in varicella-zoster virus-infected cells and kinetic properties of the virus-induced thymidine kinase. J. Virol. 31, 172-177.

Chirgwin, J. M., Przybyla, A. E., MacDonald, R. J., and RUTTER, W. J. (1979). Isolation of biologically active ribonucleic acid from sources enriched in ribonuclease. Biochemistry 18, 5294-5299.

Dobersen, M. J., JeRkofsky, M., and GreER, S. (1976). Enzymatic basis for the selective inhibition of varicella-zoster virus by 5-halogenated analogues of deoxycytidine. J. Virol. 20, 478-486.

Fyfe, J. A., Biron, K. K., McKeE, S. A., Kelly, C. M., Elion, G. B., and SAIKE, K. F. (1982). Acyclovir Symposium. Activation and antiviral effect of acy- clovir in cells infected with a varicella-like simian virus. Amer. J. Med. 73, 58-61.

Fyfe, J. A., Keller, P. M., Furman, P. A., Miller, R. L., and ELIoN, G. B. (1978). Thymidine kinase from herpes simplex virus phosphorylates the new antiviral compound, 9-(2-hydroxyethoxymethyl) guanine. J. Biol. Chem. 253, 8721-8727.

Glisin, V., Crkvenjakov, R., and Byus, C. (1974). Ribonucleic acid isolated by cesium chloride centrifugation. Biochemistry 13, 2633-2637.

GRAHAM, F. L., and VAN DER EB, A. J. (1973). A new technique for the assay of infectivity of human adenovirus 5 DNA. Virology 52, 456-467.

Hackstadt, T., and Mallavia, L. P. (1978). Deoxypyrimidine nucleoside metabolism in varicella-zoster virus-infected cells. J. Virol. 25, 510-517.

KIT, S., and LEUNG, W-C. (1974). Submitochondrial localization and characteristics of thymidine kinase molecular forms in parental and kinasc-deficient HeLa cells. Biochem. Genet. 11, 231-247.

Kit, S., Leung, W-C., and Trkula, D. (1973). Properties of mitochondrial thymidine kinases of parental and enzyme-deficient HeLa cells. Arch. Biochem. Biophys. 158, 503-513.

LITTLEFIELD, J. (1963). The inosinic acid phosphorylase activity of mouse fibroblasts partially resistant to 8-azaguanine. Proc. Natl. Acad. Sci. USA 50, 568573.

Lopetegui, P., Matsunaga, Y., Okuno, T., Ogino, T., and YAMANISHI, K. (1983). Expression of varicellazoster virus-related antigens in biochemically transformed cells. J. Gen. Virol. 64, 1181-1186.

MaITlaND, N. J., and MCDougall, J. K. (1977). Biochemical transformation of mouse cells by fragments of herpes simplex virus DNA. Cell 11, 233241.

Marsden, H. S., HAarR, L., and PReston, C. M. (1983). Processing of herpes simplex virus proteins and evidence that translation of thymidine kinase mRNA is initiated at three separate AUG codons. J. Virol. 46, 434-445.

McDougall, J. K., Masse, T. H., and Galloway, D. A. (1980). Location and cloning of the herpes simplex virus type 2 thymidine kinase gene. $J$. Virol. $33,1221-1224$.

MCKNIGHT, S. L. (1980). The nucleotide sequence and transcript map of the herpes simplex virus thymidine kinase gene. Nucleic Acids Res. 8, 5949-5964. Munyon, W., Kraiselburd, E., Davis, D., and ManN, J. (1971). Transfer of thymidine kinase to thymidine kinaseless $\mathrm{L}$ cells by infection with ultraviolet-irradiated herpes simplex virus. J. Virol. 7, 813-820.

OGINO, T., OTSUKA, T., and TAKAHASH, M. (1977). Induction of deoxypyrimidine kinase activity in human embryonic lung cells infected with varicellazoster virus. $J$. Virol. 21, 1232-1235. 
OStrove, J. M., Reinhold, W., FAN, C.-M., ZoRN, S., HaY, J., and Straus, S. E. (1985). Transcription mapping of the varicella-zoster virus genome. $J$. Virol. 56, 600-606.

Pellicer, A., Wigler, M., AXel, R., and SLverSTEIN, S. (1978). The transfer and stable integration of the HSV thymidine kinase gene into mouse cells. Cell 14, 133-141.

Rave, N., Crkvenjakov, R., and Boedtker, H. (1979). Identifieation of procollagen mRNAs transferred to diazobenzyloxymethyl paper from formaldehyde agarose gels. Nucleic Acid Res. 6, 3559-3567.

REYES, G. R., JEANG, K-T., and HAYWARD, G. S. (1982). Transfection with the isolated herpes simplex virus thymidine kinase genes. I. Minimal size of the active fragments from HSV-1 and HSV-2. J. Gen. Virol. 62, 191-206.

Shiraki, K., Ogino, T., Yamanishi, K., and TakaHASHI, M. (1985). Inmmunochemical characterization of pyrimidine kinase induced by varicella-zoster virus. J. Gen. Virol. 66, 221-229.

SOUTHERN, E. M. (1975). Detection of specific sequences among DNA fragments separated by gel electrophoresis. J. Mol. Biol. 98, 503-517.
Straus, S. E., Owens, J., Ruyechan, W. T., TakifF, H. E., CASEY, T. A., VANDE WoUdE, G.F., and HAY, J. (1982). Molecular cloning and physical mapping of varicella-zoster virus DNA. Proc. Natl. Acad. Sci. USA 72, 1184-1188.

Swain, M. A., and GaLloway, D. A. (1983). Nucleotide sequence of the herpes simplex virus type 2 thymidine kinase gene. J. Virol. 46, 1045-1050.

WAGNER, M. J., Sharp, J. A., and Summers, W. C. (1981). Nuclentide seruence of the thymidine kinase gene of herpes simplex virus type 1. Proc. Natl. Acad. Sci. USA 78, 1441-1445.

Wigler, M., Pellicer, A., Silverstein, S., and Axel, R. (1978). Biochemical transfer of single-copy eucaryotic genes using total cellular DNA as donor. Cell 14, 725-731.

Wigler, M., SLlverstein, S., LeE, L.-S., Peldicer, A., Cheng, Y.-C., and AXEL, R. (1977). Transfer of purified herpes virus thymidine kinase gene to cultured mouse cells. Cell 11, 223-232.

Yamanishi, K., MatsunaGa, Y., OGINo, T., and LoPETEGUI, P. (1981). Biochemical transformation of mouse cells by varicella-zoster virus. J. Gen. Virol. 56, $421-430$. 